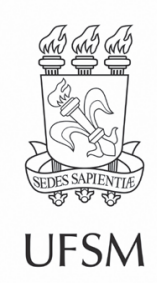

\title{
Artigos
}

\section{The species used in urban afforestation can present phytotoxicity - a case of study of Schinus molle L.}

\author{
Espécies utilizadas em arborização urbana podem apresentar \\ fitotoxicidade - um estudo de caso em Schinus molle L.
}

\section{Marina Lima Nogueira ${ }^{\oplus}$, Nádia Alves Campos " $\odot$,

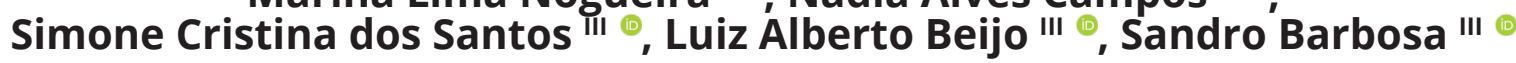

\author{
' Universidade de São Paulo, Piracicaba, SP, Brazil \\ "Katholieke Universiteit Leuven, Leuven, Belgium \\ III Universidade Federal de Alfenas, Alfenas, MG, Brazil
}

\begin{abstract}
The aim of this study was to test the phytotoxicity and cytotoxicity of ethanolic and aqueous extracts of different structures of Schinus molle L., an ornamental species commonly used in urban afforestation in Brazil, using seeds of lettuce (Lactuca sativa L.) as its plant model. The extracts were prepared from samples of leaves, inflorescence, green and ripe fruits collected in fields located in Alfenas, state of Minas Gerais, Brazil. The parameters assessed were germination (G), germination velocity index (GVI), root elongation (RE), fresh biomass (FB), dry biomass (DB), normal seedlings (NP), mitotic index (MI) and chromosomal abnormalities (CA). According to results, for the aqueous extract, we found interactions between concentration and plant structures in relation to $G, G V I, R E, D B$, and $C A$. There were no statistically significant differences among structures in relation to the percentage of normal seedlings, except among concentrations. However, the interaction for all parameters was statistically significant in relation to ethanolic extracts, except the chromosomal abnormalities. Therefore, the increasing of concentration leads to the reduction of the parameters assessed, showing a concentration-dependent effect. The ethanolic and aqueous extracts of Schinus molle showed phytotoxic effect, indicating the need for reassessment and care in the use of this species for reforestation.
\end{abstract}

Keywords: Allelopathy; Cytotoxicity; Phytotoxicity 


\section{RESUMO}

O objetivo deste estudo foi estudar a fitotoxicidade e citotoxicidade de extratos etanólico e aquoso das diferentes estruturas de Schinus molle L., uma espécie ornamental, comumente usada em arborização urbana no Brasil, utilizando sementes de alface (Lactuca sativa L.) como planta modelo. Os extratos vegetais foram preparados a partir de amostras de folhas, inflorescências, frutos verdes e maduros coletados em Alfenas, Minas Gerais, Brasil. Os parâmetros avaliados foram germinação (G), índice de velocidade de germinação (GVI), comprimento radicular (RE), biomassa fresca (FB), biomassa seca (DB), porcentagem de plântulas (PS), índice mitótico (MI) e anomalias cromossômicas (CA). De acordo com os resultados, para o extrato aquoso, encontramos interações entre as estruturas e as concentrações utilizadas em relação a $G, G V I, R E, D B$, e CA. Não houve diferença significativa entre as estruturas vegetais em relação à porcentagem de plântulas normais, exceto para as concentrações. No entanto, para todos os parâmetros foi encontrada diferença significativa em relação ao extrato etanólico, exceto para anormalidades cromossômicas. O aumento da concentração leva à redução de todos os parâmetros avaliados, mostrando o efeito concentração-dependente. Os extratos etanólico e aquoso de Schinus molle mostraram efeito fitotóxico, indicando a necessidade de reavaliação e cuidado no uso dessa espécie para o reflorestamento.

Palavras-chave: Alelopatia; Citotoxicidade; Fitotoxicidade

\section{INTRODUCTION}

Schinus molle L. is a plant species from Anacardiaceae family originating from Latin America. In Brazil, it can be found from Minas Gerais to Rio Grande do Sul states. Popular named as Aroeira-salsa, Aroeira-mansa or Aroeirinha, this species has a xerophytic habit, surviving in steep areas and dry environments, and has been used in popular medicine, landscaping and logger purposes (FENNER et al., 2006) and in the phytoremediation (PEREIRA et al., 2013b). In the pharmaceutical industry, Schinus molle is important by having leaves and fruits containing essential oils with a variety of properties such as antimicrobial, antioxidant, antifungal, antispasmodic, antipyretic, anti-inflammatory and wound healing (SANTOS et al., 2007; MARTINS et al., 2014). Plants in general ha capacity of competing with other plants and with other organisms using special chemical compounds called secondary metabolites, which play an important role in the species adaptation, organization and composition of plant communities (FERREIRA; ÁQUILA, 2000; REIGOSA et al., 2013). When these chemicals interact with other plants, impacting the surrounding environment, they are called allelochemicals 
and can cause direct or indirect effect, harmful or beneficial between plants and other organisms.

Allelochemicals can be found in all plant organs, and can be released into the environment by leaching tissues, dissolved into water, either from aerial parts or from roots, and through volatilization of aromatic compounds (RICE, 1984; GOBBO-NETO; LOPES, 2007; NASCIMENTO et al., 2012; GOVÊA et al., 2020). There are few papers dealing with the biological effect of allelochemicals from Schinus molle (ZAHED et al., 2010; PAWLOWSKI et al., 2012; NOGUEIRA et al., 2017). In this context, to investigate the phytotoxic effect of secondary compounds of this plant species, as well as its effect toward cytogenetic aspects, one may provide very important information about its use in the re-arborization of degraded areas or its potential use in bioherbicide production. Therefore, the aim of this work was to investigate the effect of ethanolic and aqueous extracts from different structures of Schinus molle, in different concentrations, in bioassay with lettuce (Lactuca sativa L.).

\section{METHODOLOGY}

\subsection{Sample Collection}

The plant material was collected in Alfenas, state of Minas Gerais, Brazil. Collections were performed from September to November 2012 in areas located between $\left(21^{\circ} 25^{\prime} 44^{\prime \prime} \mathrm{S}\right.$ and $\left.45^{\circ} 56^{\prime} 49^{\prime \prime} \mathrm{W}\right)$, and at $768 \mathrm{~m}$ of mean altitude. Leaves completely expanded were collected in the absence of any reproductive structure. Inflorescences were collected during flowering time and fruits in different stages (green and ripe fruits). The dried specimen with fertile material is available in the herbarium of the Federal University of Alfenas, under the number 2529.

All collected material was dried in oven at $40^{\circ} \mathrm{C}$ until mass stabilization. Then, the distinct structures were separately triturated, sieved at 20 fine sieve in order to obtain the ethanolic and aqueous extracts. The ethanolic extract was prepared by macerating 
and adding pure ethanol to the plant material until total exhaustion of the macerated product and, then, concentrated in a rotary evaporator. The $5 \%$ aqueous extract was prepared using the infusion method, as outlined by Brasil (2010) and then lyophilized.

\subsection{Phytotoxic Test}

The phytotoxicity test was carried out as described by Ribeiro et al. (2012) and Simões et al. (2013), using 3 replicates of 50 seeds of lettuce (Lactuca sativa cv. Grand rapids), in Petri dishes containing $5 \mathrm{ml}$ of the different concentrations $(0,5,10,20$ e 40 $\mathrm{mg} \cdot \mathrm{mL}^{-1}$ ) of ethanolic and aqueous extracts of all Schinus molle structures tested.

The experiment was performed in a germination chamber under a 12-hour photoperiod at $25^{\circ} \mathrm{C}$. The germination was assessed each 12 hours, during 7 days, which allowed determining the germination velocity index, as follows:

$\mathrm{GVI}=\left(\mathrm{G}_{1} / \mathrm{N}_{1}\right)+\left(\mathrm{G}_{2} / \mathrm{N}_{2}\right)+\ldots+\left(\mathrm{G}_{\mathrm{n}} / \mathrm{N}_{\mathrm{n}}\right)$

in where: $\mathrm{GVI}=$ germination velocity index; $\mathrm{G}=$ number of seeds germinated in the $i$ counting $(i=1,2,3, \ldots, n)$, and $N=$ number of days until the $i$ counting $(i=1,2,3, \ldots, n)$.

In the $7^{\text {th }}$ day, the germination rate $(G)$, normal seedlings (NP), root elongation $(\mathrm{RE})$, and fresh biomass (FB) were assessed. For measuring RE, FB and dried biomass (DB), 10 normal seedlings were used, randomly selected from each Petri dish.In cases of Petri dishes with less than 10 normal seedlings, the mean weight of the existing ones was calculated. After FB collection, the seedlings were placed into the oven with air circulation at $45^{\circ} \mathrm{C}$, until mass stabilization for assessing DB.

\subsection{Cytotoxicity Test}

The experiment was performed aiming to assess the effect of Schinus molle extracts in the cell cycle, and chromosomal complement of the target-plant as outlined by Ribeiro et al. (2012) and Pereira et al. (2013a). Thirty seeds of lettuce were incubated in Petri dishes containing $3 \mathrm{~mL}$ of ethanolic and aqueous extracts, in the same conditions of the phytotoxicity test. Then, 3000 cells per treatment were checked aiming to assess 
the mitotic index (MI) and chromosomal abnormalities (CA) as described by AndradeVieira et al. (2014). The assessed CA were chromosomal bridges, micronucleus, missing chromosomes, C-metaphase and sticky chromosomes.

\subsection{Data Analysis}

Two experiments were performed in completely randomized blocks, with three replicates; one aiming to test the effect of aqueous extract, and another aiming to test the effect of ethanolic extract. Both were performed in $4 \times 5$ factorial scheme, with four plant structures (leaf, inflorescence, green fruit, and ripe fruit), and five concentrations $\left(0,5,10,20\right.$ and $\left.40 \mathrm{mg} \cdot \mathrm{mL}^{-1}\right)$.

The analysis of variance (ANOVA) was carried out to determine the statistical significance of the plant structure means. The normality test was run and, when data were considered with no Gaussian normal distribution, they were transformed in order to attend the assumptions of ANOVA through square root transformation. Means were compared by Scott-Knot test at 5\% significance level using R statistical software (R DEVELOPMENT CORE TEAM, 2013). For assessing the effect of concentration, regression models were adjusted in all cases when possible.

\section{RESULTS AND DISCUSSION}

When seeds of lettuce were exposed to aqueous extracts of Schinus molle, it was possible to find the interaction effect among structures and extracts concentration for $\mathrm{GVI}(p=0.0015), \mathrm{G}(p=0.0025), \mathrm{RE}(p=0.0029)$ and $\mathrm{DB}(p<0.0001)$. There was no interaction among variation sources $(p=0.17)$ for FB. However, when concentration $(p<0.0001)$ and extract $(p=0.011)$ were assessed separately, a statistic significance could be observed. For NP, there was no interaction $(p=0.16)$, but statistically significant difference only among concentrations $(p<0.0001)$ was found.

The aqueous extracts obtained from ripe fruits had the least interferences, in relation to $G, G V I, R E$ and $D B$ (Table 1). In relation to $G$, the effect of extracts obtained 
from different plant structures were only different at 20 and $40 \mathrm{mg} \cdot \mathrm{mL}^{-1}$. For all the other concentrations, all extracts had the same interference pattern. At $20 \mathrm{mg} \cdot \mathrm{mL}^{-1}$, the extract obtained from green fruits had the highest negative effect in relation to G. For $40 \mathrm{mg} \cdot \mathrm{mL}^{-1}$ the highest interferences were found in the extracts obtained from leaves and inflorescence (Table 1).

Table 1 - Mean of Germination (\%), Germination Velocity Index, Root Elongation (mm) and Dry Biomass (mg) of Lactuca sativa exposed to different concentrations of aqueous extracts obtained from distinct plant structures from Schinus molle

\begin{tabular}{|c|c|c|c|c|c|}
\hline \multirow{2}{*}{ Plant structure } & \multicolumn{5}{|c|}{ Concentrations (mg.mL-1) } \\
\hline & 0 & 5 & 10 & 20 & 40 \\
\hline & \multicolumn{5}{|c|}{ Germination (\%) } \\
\hline Ripe Fruit & $93 a$ & $97 a$ & $100 \mathrm{a}$ & $91 \mathrm{a}$ & $33 a$ \\
\hline Green Fruit & $97 a$ & $97 a$ & $91 \mathrm{a}$ & $71 \mathrm{~b}$ & $45 \mathrm{a}$ \\
\hline Leaf & $100 \mathrm{a}$ & $96 a$ & $91 \mathrm{a}$ & $86 a$ & $9 \mathrm{~b}$ \\
\hline \multirow[t]{2}{*}{ Inflorescence } & $98 \mathrm{a}$ & $98 \mathrm{a}$ & $95 a$ & $96 a$ & $21 \mathrm{~b}$ \\
\hline & \multicolumn{5}{|c|}{ Germination Velocity Index } \\
\hline Ripe Fruit & $23,55 \mathrm{a}$ & $23,26 a$ & $21,13 a$ & $13,97 \mathrm{a}$ & $2,2 \mathrm{a}$ \\
\hline Green Fruit & $22,87 \mathrm{a}$ & $22,62 \mathrm{a}$ & $18,52 \mathrm{a}$ & $9,67 b$ & $2,17 \mathrm{a}$ \\
\hline Leaf & $23,47 a$ & $16,32 b$ & $10,42 \mathrm{~b}$ & $4,76 \mathrm{c}$ & $0,39 a$ \\
\hline \multirow[t]{2}{*}{ Inflorescence } & 21,63 a & $18,97 \mathrm{~b}$ & $13,57 b$ & $4,75 \mathrm{c}$ & $1,09 a$ \\
\hline & \multicolumn{5}{|c|}{ Root Elongation (mm) } \\
\hline Ripe Fruit & 40,71 a & $26,03 a$ & 19,91 a & $3,33 a$ & $3,43 a$ \\
\hline Green Fruit & 49,93 a & $20,27 a$ & $8,92 \mathrm{~b}$ & $3,35 a$ & $0,00 \mathrm{a}$ \\
\hline Leaf & 47,39 a & $12,21 \mathrm{~b}$ & 7,56 b & $5,25 a$ & $0,00 \mathrm{a}$ \\
\hline \multirow[t]{2}{*}{ Inflorescence } & 46,28 a & $20,82 \mathrm{a}$ & 15,43 a & $8,21 \mathrm{a}$ & $0,00 \mathrm{a}$ \\
\hline & \multicolumn{5}{|c|}{ Dry Biomass (mg) } \\
\hline Ripe Fruit & $0,081 \mathrm{a}$ & $0,085 a$ & 0,093 a & $0,083 a$ & $0,059 a$ \\
\hline Green Fruit & 0,092 a & $0,089 a$ & $0,083 a$ & $0,069 a$ & $0,000 \mathrm{~b}$ \\
\hline Leaf & $0,086 a$ & $0,084 a$ & 0,081 a & $0,074 a$ & $0,000 \mathrm{~b}$ \\
\hline Inflorescence & $0,077 \mathrm{a}$ & $0,081 \mathrm{a}$ & $0,071 \mathrm{a}$ & $0,068 \mathrm{a}$ & $0,003 \mathrm{~b}$ \\
\hline
\end{tabular}

Source: Authors (2015)

In where: Averages followed by the same letter in the columns do not differ by ScottKnot test at 5\% significance level.

For $\mathrm{GVI}$ and $\mathrm{RE}$, the distinction between the tested structures was possible, even 
at the lowest concentration of extracts. However, in high concentrations there was no statistically significant differences. This was probably due to high interference of the high concentrations. Indeed, for GVI, means were close to zero and, for RE, they were statistically equal to zero, both at $40 \mathrm{mg} \cdot \mathrm{mL}^{-1}$. In relation to $\mathrm{GVI}$, the greatest reductions were found in extracts obtained from leaves and inflorescence and, in relation to RE, it was found in extracts obtained from leaves and green fruits (Table 1).

The DB was found to be less sensitive to differences among structures, with statistically significant differences only at $40 \mathrm{mg} \cdot \mathrm{mL}^{-1}$, when obtaining of seedlings was almost null (Table 1). For FB, regardless the concentration, the least interference was found when the extract obtained from ripe fruits $(1.1 \mathrm{mg})$ was considered. There was no statistically significant differences among extracts obtained from green fruits $(0.89 \mathrm{mg})$, leaves (0.84 mg) and inflorescence (0.93 mg).

When lettuce seeds were exposed to aqueous extracts obtained from different structures of Schinus molle, the increasing of concentration leads to reduction in the response for all parameters, showing a concentration dependent effect (Figure 1).

Figure 1 - Relation among aqueous extract concentrations of different Schinus molle structures

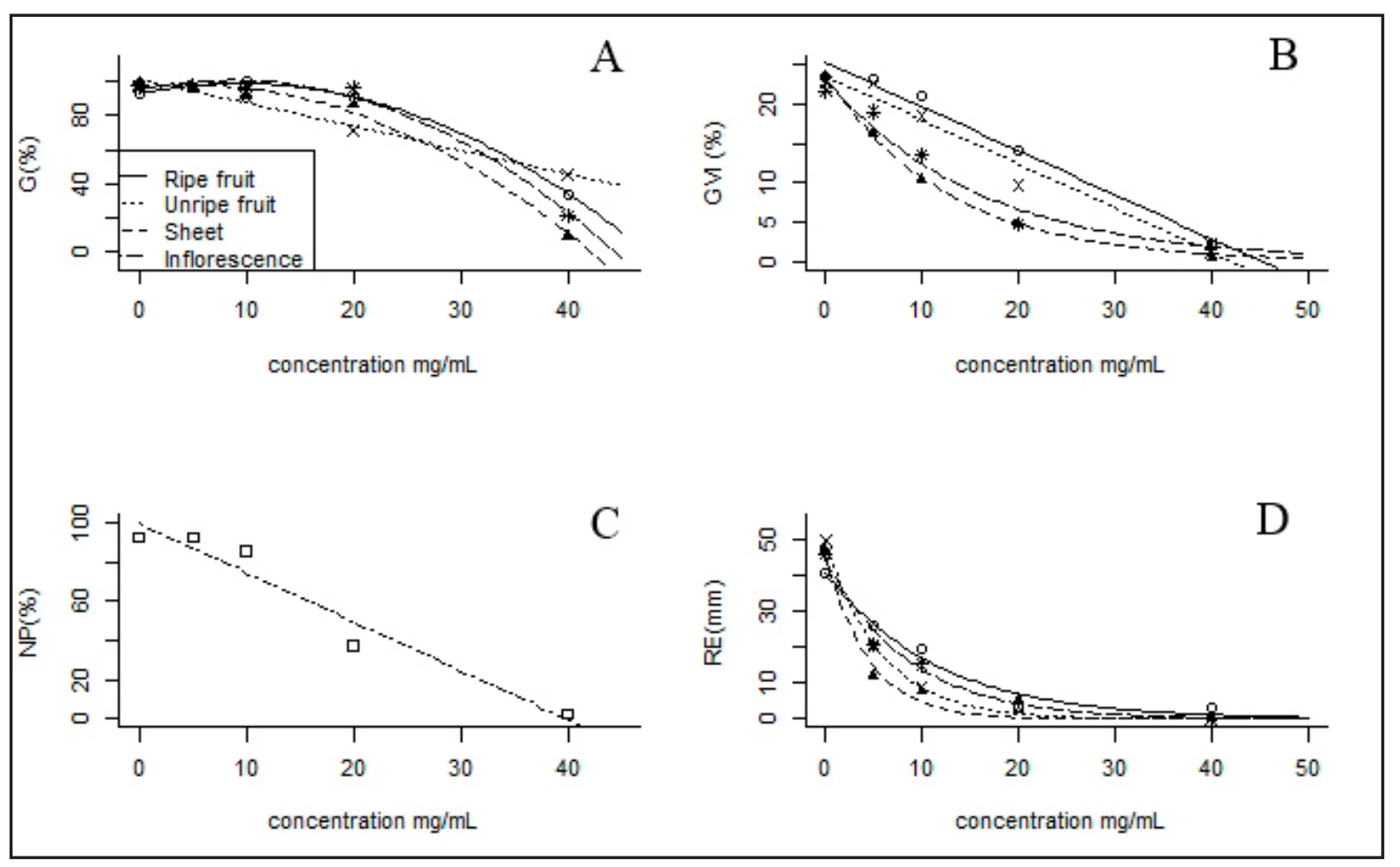

Continued ... 
Figure 1 - Conclusion

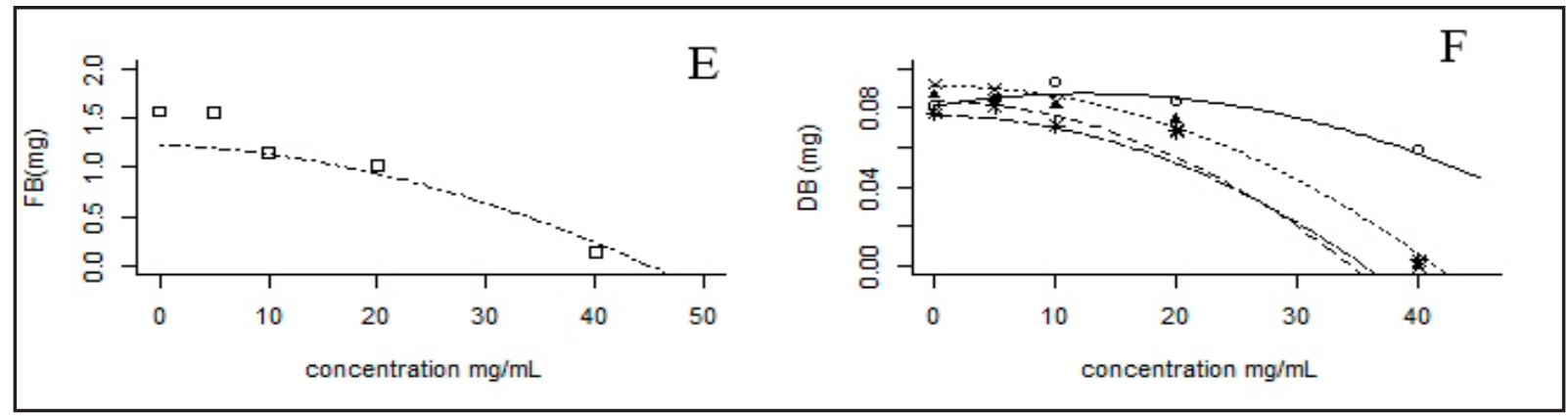

Source: Authors (2015)

In where: A: G\% (Ripe Fruit=93,01+1,29X-0,069X2, $R^{2}=0,99$; green fruit= 100-1,4X, $R^{2}=0,97$; leaf $=96,74+0,65 X-0,07 X^{2}, R^{2}=0,98$; inflorescence $\left.=94,86+1,4 X-0,08 X^{2}, R^{2}=0,98\right) ; B: G V I$ (ripefruit $=25,32-$ $0,56 X, R^{2}=0,98$; green fruit $=23,56-0,56 X, R^{2}=0,96$; leaf $=23,70^{(-0,08 x)}, R^{2}=0,99$; inflorescence $=23,13^{-}$ $\left.0,062 x), R^{2}=0,95\right) ; C: N P \%\left(Y=43,33-1,19 X, R^{2}=0,97\right) ; D: R E$ (ripe fruit $=41,02^{(-0,87 x)}, R^{2}=0,97$; green fruit $=49,73^{(-0,173 x)}, R^{2}=0,99$; leaf $=46,96^{(-0,233 x)}, R^{2}=0,97$; inflorescence $\left.=44,73^{(-0,116 x)}, R^{2}=0,97\right) ; E: F B$ $\left(Y=1,239-0,0048 X-0,0005 X^{2}, R^{2}=0,98\right)$ and $F: D B$ (ripe fruit $=0,081+0,001 X-0,00004 X^{2}, R^{2}=0,93$; green fruit $=0,0911-0,000053 X^{2}, R^{2}=0,99$; leaf $=0,083-0,00007 X^{2}, R^{2}=0,99$; inflorescence $=0,076-0,00006 X^{2}$, $\left.\mathrm{R}^{2}=0,98\right)$.

When seeds of lettuce were exposed to ethanolic extracts of Schinus molle, we found a significant effect of interaction among structures and extract concentrations for GVI $(p=0.0016), G(p=0.033)$, NP $(p<0.0001)$, RE $(p=0.0013)$, FB $(p=0.014)$ and DB $(p=0.004)$. In the highest concentration, we found high toxicity of the extract obtained from green fruits (Table 2).

Table 2 - Germination (\%), germination velocity index, normal seedlings (\%), root elongation (mm), fresh and dry biomass ( $\mathrm{mg}$ ) of Lactuca sativa seeds exposed to different concentrations of ethanolic extracts, obtained from distinct plant structures of Schinus molle

\begin{tabular}{lccccc}
\hline \multirow{2}{*}{ Plant structure } & \multicolumn{5}{c}{ Concentrations (mg.mL-1) } \\
\cline { 2 - 6 } & $\mathbf{0}$ & $\mathbf{5}$ & $\mathbf{1 0}$ & $\mathbf{2 0}$ & $\mathbf{4 0}$ \\
\hline Ripe Fruit & $100 \mathrm{a}$ & $100 \mathrm{a}$ & $98 \mathrm{a}$ & $94 \mathrm{a}$ & $74 \mathrm{a}$ \\
Green Fruit & $91 \mathrm{a}$ & $97 \mathrm{a}$ & $88 \mathrm{a}$ & $71 \mathrm{~b}$ & $51 \mathrm{~b}$
\end{tabular}

Continued ... 
Table 2 - Continuation

\begin{tabular}{|c|c|c|c|c|c|}
\hline \multirow{2}{*}{ Plant structure } & \multicolumn{5}{|c|}{ Concentrations (mg.mL $\mathrm{mL}^{-1}$ ) } \\
\hline & 0 & 5 & 10 & 20 & 40 \\
\hline & \multicolumn{5}{|c|}{ Germination (\%) } \\
\hline Leaf & $98 \mathrm{a}$ & $93 a$ & $90 \mathrm{a}$ & $85 a$ & $41 \mathrm{~b}$ \\
\hline \multirow[t]{2}{*}{ Inflorescence } & $100 \mathrm{a}$ & $89 \mathrm{a}$ & $91 \mathrm{a}$ & $84 \mathrm{a}$ & $33 \mathrm{~b}$ \\
\hline & \multicolumn{5}{|c|}{ Germination Velocity Index } \\
\hline Ripe Fruit & $23,52 \mathrm{a}$ & 21,16 a & $19,89 \mathrm{a}$ & $17,05 \mathrm{a}$ & $9,18 \mathrm{a}$ \\
\hline Green Fruit & 23,52 a & $20,79 a$ & 18,32 a & $11,56 \mathrm{~b}$ & $3,84 \mathrm{~b}$ \\
\hline Leaf & $23,81 \mathrm{a}$ & $18,40 \mathrm{a}$ & 15,92 a & $9,24 \mathrm{~b}$ & $3,31 \mathrm{~b}$ \\
\hline \multirow[t]{2}{*}{ Inflorescence } & $22,18 \mathrm{a}$ & $20,70 \mathrm{a}$ & 18,06 a & $10,95 \mathrm{~b}$ & $4,41 \mathrm{~b}$ \\
\hline & \multicolumn{5}{|c|}{ Normal Seedlings (\%) } \\
\hline Ripe Fruit & $87 \mathrm{a}$ & $92 \mathrm{a}$ & $91 \mathrm{a}$ & $83 a$ & $21 \mathrm{a}$ \\
\hline Green Fruit & $90 \mathrm{a}$ & $92 \mathrm{a}$ & $79 a$ & $44 \mathrm{~b}$ & $\mathrm{Ob}$ \\
\hline Leaf & $96 \mathrm{a}$ & $88 \mathrm{a}$ & $82 \mathrm{a}$ & $51 \mathrm{~b}$ & $5 b$ \\
\hline \multirow[t]{2}{*}{ Inflorescence } & $97 \mathrm{a}$ & $88 \mathrm{a}$ & $81 \mathrm{a}$ & $22 \mathrm{a}$ & $1 \mathrm{~b}$ \\
\hline & \multicolumn{5}{|c|}{ Root Elongation (mm) } \\
\hline Ripe Fruit & $43,34 \mathrm{a}$ & $42,26 \mathrm{a}$ & $38,24 \mathrm{a}$ & $18,73 \mathrm{a}$ & $6,21 \mathrm{a}$ \\
\hline Green Fruit & 49,03 a & $37,38 \mathrm{a}$ & $14,15 b$ & $4,17 b$ & $0,00 \mathrm{c}$ \\
\hline Leaf & $52,68 \mathrm{a}$ & $34,55 \mathrm{a}$ & $23,82 b$ & $7,88 \mathrm{~b}$ & $2,19 b$ \\
\hline \multirow[t]{2}{*}{ Inflorescence } & $53,28 a$ & $34,65 a$ & $19,68 b$ & $12,83 \mathrm{a}$ & $0,67 \mathrm{c}$ \\
\hline & \multicolumn{5}{|c|}{ Fresh Biomass (mg) } \\
\hline Ripe Fruit & $1,18 \mathrm{a}$ & $1,32 \mathrm{a}$ & $1,16 \mathrm{a}$ & $1,19 \mathrm{a}$ & $0,77 \mathrm{a}$ \\
\hline Green Fruit & $1,19 \mathrm{a}$ & $1,21 \mathrm{a}$ & $1,01 \mathrm{a}$ & $1,02 \mathrm{a}$ & $0,00 \mathrm{~b}$ \\
\hline Leaf & $1,22 \mathrm{a}$ & $1,02 \mathrm{a}$ & $1,07 \mathrm{a}$ & $0,82 \mathrm{~b}$ & $0,25 \mathrm{~b}$ \\
\hline Inflorescence & $1,19 \mathrm{a}$ & $1,27 \mathrm{a}$ & 0,93 a & $0,85 b$ & $0,17 b$ \\
\hline
\end{tabular}


Table 2 - Conclusion

\begin{tabular}{lccccc}
\hline \multirow{2}{*}{ Plant structure } & $\mathbf{5}$ Concentrations $\left(\mathbf{m g} \cdot \mathbf{m L}^{-1}\right)$ \\
\cline { 2 - 6 } & $\mathbf{0}$ & $\mathbf{5}$ & $\mathbf{1 0}$ & $\mathbf{2 0}$ & $\mathbf{4 0}$ \\
\hline Ripe Fruit & $0,077 \mathrm{a}$ & $0,088 \mathrm{a}$ & $0,088 \mathrm{a}$ & $0,085 \mathrm{a}$ & $0,08 \mathrm{a}$ \\
Green Fruit & $0,084 \mathrm{a}$ & $0,082 \mathrm{a}$ & $0,08 \mathrm{a}$ & $0,084 \mathrm{a}$ & $0,00 \mathrm{c}$ \\
Leaf & $0,079 \mathrm{a}$ & $0,079 \mathrm{a}$ & $0,079 \mathrm{a}$ & $0,065 \mathrm{a}$ & $0,03 \mathrm{~b}$ \\
Inflorescence & $0,084 \mathrm{a}$ & $0,077 \mathrm{a}$ & $0,069 \mathrm{a}$ & $0,072 \mathrm{a}$ & $0,023 \mathrm{~b}$ \\
\hline
\end{tabular}

Source: Authors (2015)

In where: Averages followed by the same letter in the column do not differ from another by Scott-Knott test at 5\% of significance level.

With the increasing of extract concentration, we found a reduction in the response for all parameters, showing a concentration dependent effect, except DB for the extract obtained from ripe fruits. For DB, we did not found statistically significant differences, i.e., the ethanolic extract of ripe fruits did not cause interference in the DB of lettuce seedlings (Figure 2F).

Figure 2 - Relation among ethanolic extract concentrations of Schinus molle different structures

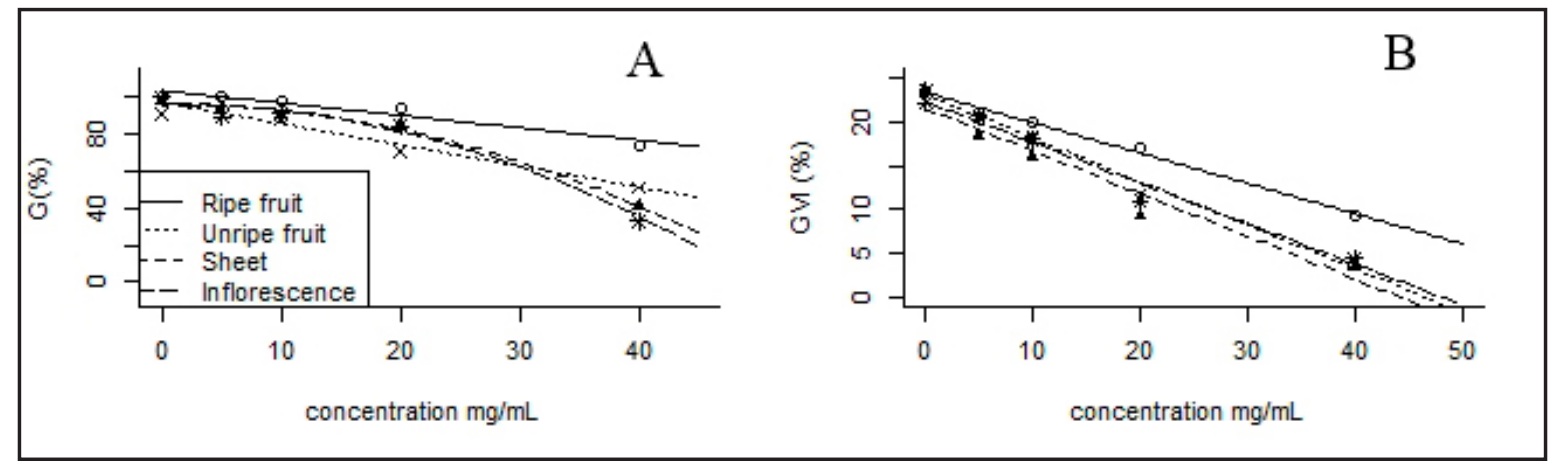

Continued ... 
Figure 2 - Conclusion

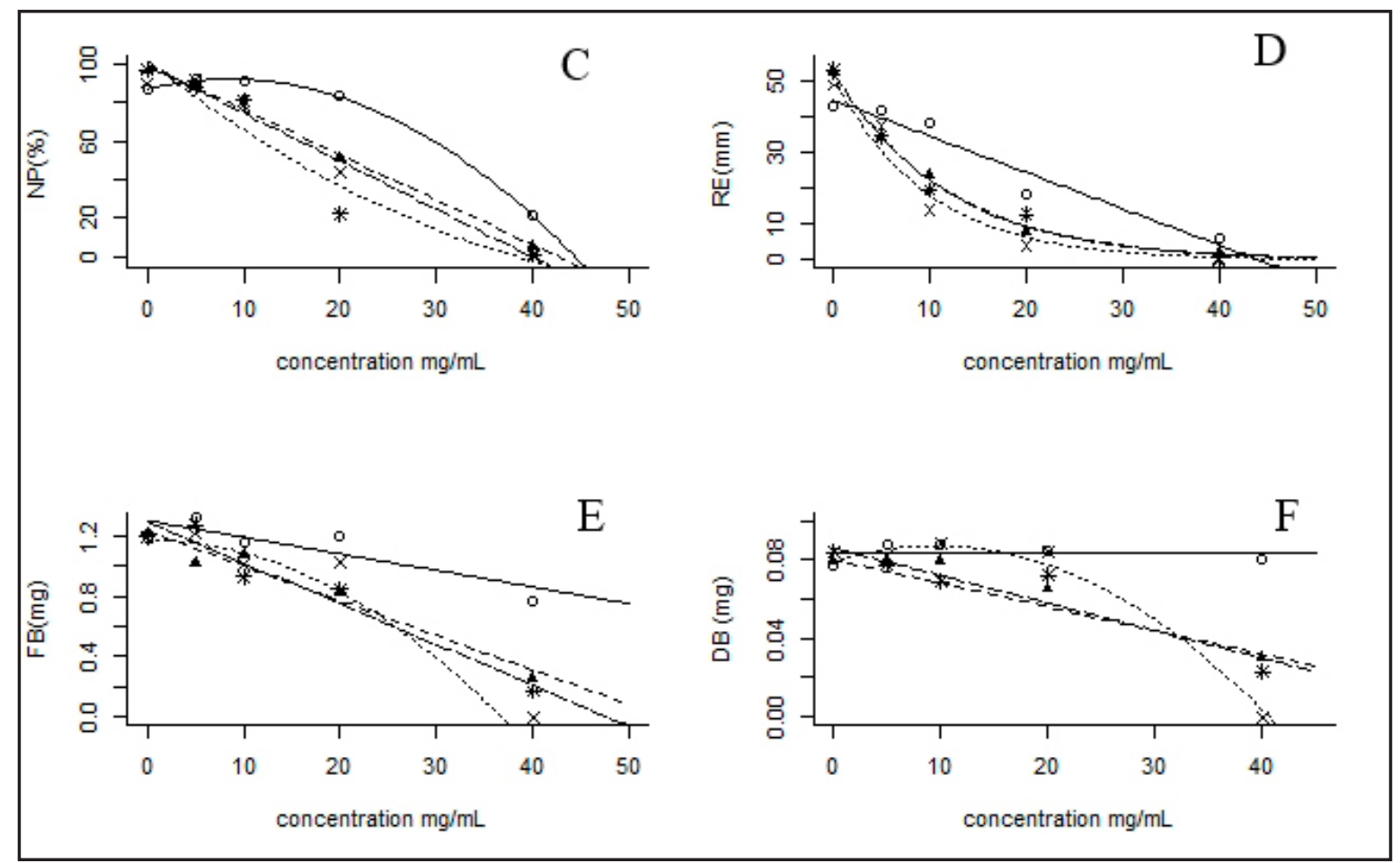

Source: Authors (2015)

Where: A: G\% (ripe fruit=100-0,67X, $R^{2}=0,92$; green fruit $=96,97-1,14 X, R^{2}=0,93$; leaf $=96,45$ $0,025 X-0,034 X^{2}, \quad R^{2}=0,99 ; \quad$ Inflorescence $=95,72+0,09 X-0,04 X^{2}, \quad R^{2}=0,97$ ); $B: \quad G V I$ (ripe fruit $=4,88-0,045 X, R^{2}=0,98$, green fruit $=4,91-0,074 X, R^{2}=0,99$, leaf $=4,74-0,075 X, R^{2}=0,98$, inflorescence $=4,82-0,075 X, R^{2}=0,98$ ); $C$ : $N P \%$ (ripe fruit $=86,73+1,25 X-0,07 X^{2}, R^{2} 0,99 ;$ green fruit=100-2,34X, $R^{2}=0,91$; leaf=99,63-2,34X, $R^{2}=0,99$; Inflorescence =99,45-2,49X, $R^{2}=0,98$ ); $D$ : $R E$ (ripe fruit $=6,88-0,11 X, R^{2}=0,97$, green fruit $=51,37^{(-0,104 x)}, R^{2}=0,95$; leaf $=52,94^{(-0,085 x)}, R^{2}=0,99$; Inflorescence $\left.=52,85^{(-0,086 x)}, R^{2}=0,98\right)$; $E$ : FB (ripe fruit $=1,3-0,011 X, R^{2}=0,75$; green fruit $=1,17$ $0,00087 X^{2}, R^{2}=0,97$; leaf $=1,23-0,023 X, R^{2}=0,96$; inflorescence=1,29-0,027X, $R^{2}=0,94$ ); $F$ : $D B$ (ripe fruit $=0,0836$ [there was no effect], green fruit $=0,079-0,00009 X^{2}, R^{2}=0,97$; leaf $=0,08-0,0012 X$, $\mathrm{R}^{2}=0,92$; inflorescence $=0,086-0,014 \mathrm{X}, \mathrm{R}^{2}=0,88$ ).

In relation to $\mathrm{MI}$, the interphase, prophase, metaphase, anaphase and telophase were quantified. Regarding to CA, in this analysis we assessed chromosomal bridges, micronucleus, missing chromosomes, C-metaphase and stickiness (Figure 3).

In the cytotoxicity test, we found interaction among extracts concentrations and structures, when assessed CA in meristematic tissues of roots exposed to aqueous extracts $(p<0.0001)$. There was no statistically significant interaction among concentrations and structures $(p=0.46)$, in relation to MI. However, either concentration 
$(p<0.0001)$ or plant structures $(p=0.010)$ effects were statistically significant, when assessed separately.

Mean of MI hints that the aqueous extract also showed concentration dependent effect, so that the increasing of concentration led to the index reduction, adjusted to the regression model: $\left[Y=35,69-1,07 X\left(R^{2}=0,98\right)\right]$. The highest reduction of $\mathrm{MI}$ means was found when meristematic cells were exposed to green fruits extracts (27.4\%), regardless to concentration, with no statistically significant differences among extracts of ripe fruits (32.05\%), leaves (31.19\%) and inflorescence (30.77\%).

Figure 3 - Phases of cellular division used to obtain the mitotic index and chromosomal abnor malities quantified

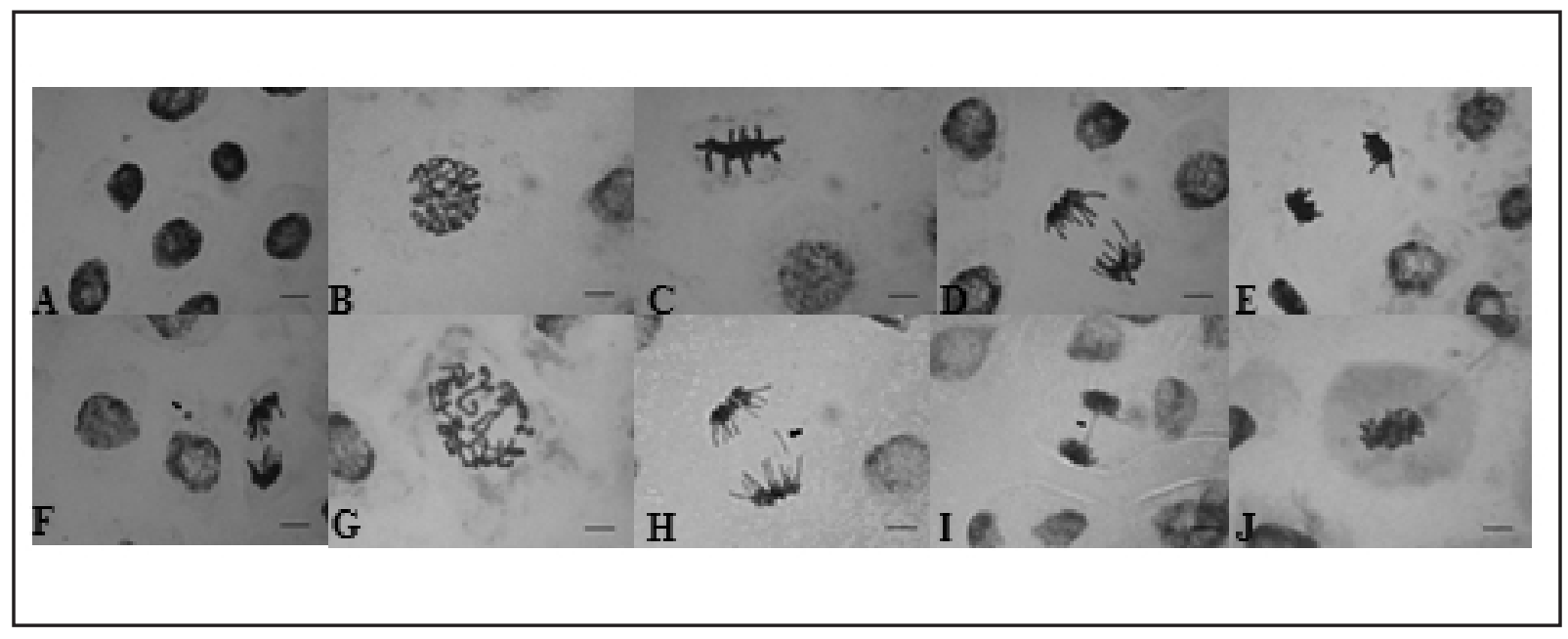

Source: Authors (2015)

In where: A: interphase; B: prophase; C: metaphase; D: anaphase; E: telophase; F: micronucleus; G: C-metaphase; $\mathrm{H}$ : missing chromosomes; I: chromosomal bridges; J: stickiness.

Percentage of abnormalities at $5 \mathrm{mg} \cdot \mathrm{mL}^{-1}$ was statistically equal in all aqueous extracts. At concentration $10 \mathrm{mg} \cdot \mathrm{mL}^{-1}$ aqueous extracts of Leaf, Green fruit and Inflorescence were no active compare to the control, except for the extract from the ripe fruit, that showed an increase of CA in the same concentration (Table 3).

Differing from the results observed for aqueous extracts, for ethanolic extracts we found statistically significant interaction among concentrations and structures, in 
relation to $\mathrm{MI}(p=0.0088)$. However, the same interaction was not significant, in relation to CA $(p=0.0650)$, but statistically significant either for concentration $(p<0.0001)$ or for plant structures $(p=0.0009)$, when assessed separately.

Table 3 - Chromosomal abnormalities (\%) in meristematic cells of the radicular apex of Lactuca sativa exposed to different concentrations of Schinus molle aqueous extracts obtained from distinct structures

\begin{tabular}{lccc}
\hline \multirow{2}{*}{ Plant structure } & \multicolumn{3}{c}{ Concentrations $\left(\mathbf{m g} \cdot \mathbf{m L}^{-1}\right)$} \\
\cline { 2 - 4 } & $\mathbf{0}$ & $\mathbf{5}$ & $\mathbf{1 0}$ \\
\hline Ripe Fruit & $1,70 \mathrm{Ba}$ & $2,67 \mathrm{Aa}$ & $2,87 \mathrm{Aa}$ \\
Green Fruit & $1,87 \mathrm{Aa}$ & $2,40 \mathrm{Aa}$ & $0,90 \mathrm{Bb}$ \\
Leaf & $1,63 \mathrm{Ba}$ & $2,80 \mathrm{Aa}$ & $0,35 \mathrm{Cb}$ \\
Inflorescence & $1,67 \mathrm{Aa}$ & $2,17 \mathrm{Aa}$ & $0,57 \mathrm{Bb}$ \\
\hline
\end{tabular}

Source: Authors (2015)

In where: Averages followed by the same capital letter in the row, and lowercase letters in the column do not differ from another by Scott-Knot test at $5 \%$ significance level.

The ethanolic extract obtained from leaves showed the lowest MI, regardless concentration (Table 4). All extracts showed negative effect, with no statistical differences among extract concentrations of the green fruit, leaf and inflorescence. However, for ripe fruit extract, both concentrations showed a decrease in MI compared to control, where for $5 \mathrm{mg} \cdot \mathrm{mL}^{-1}$ the lowest mitotic activity was observed.

The percentage of abnormalities observed for the ethanolic extracts was greater for the extracts obtained from ripe fruits (1.81\%) and leaves (1.68\%) than those obtained from green fruits (1.1\%) and inflorescence (1.22\%). No statistically significant differences were detected among the control (1.81\%) and $5 \mathrm{mg} \cdot \mathrm{mL}^{-1}(1.72 \%)$, but both were higher than that of $10 \mathrm{mg} \cdot \mathrm{mL}^{-1}(0.83)$.

In order to outperform the abiotic pressures exerted in the environment and the competition among plants, some species have developed defense mechanisms through biosynthetic pathways. They synthesize and accumulate a variety of secondary metabolites, which play an important role in the ecological interactions. 
These metabolites, also called allelochemicals, may affect the establishment and development of plant species that occur in same areas (FERREIRA; AQUILA, 2000; SANTOS, 2007;NASCIMENTO et al., 2012). These substances can be synthesized in all plant structures, varying in content and composition (ALVES; ARRUDA; SOUZA FILHO, 2002). Generally, young tissues tend to produce higher quantities of secondary metabolites than senescent tissues, even metabolites that cause toxicity in the structure that produce them, which can help plants to avoid the herbivory (SINIMBU; COLEY; LEMES, 2012). Then, the more evident toxicity in young tissues was also found in this study, since aqueous and ethanolic extracts of green fruits were found to have higher toxicity than the other structures in the majority of parameters.

Table 4 - Mitotic index (\%) in meristematic cells of the radicular apex of Lactuca sativa exposed to different concentrations of ethanolic extracts obtained from distinct Schinus molle structures

\begin{tabular}{lccc}
\hline \multirow{2}{*}{ Plant structure } & \multicolumn{3}{c}{ Concentrations $\mathbf{( m g \cdot \mathbf { m l } ^ { - \mathbf { 1 } } )}$} \\
\cline { 2 - 4 } & $\mathbf{0}$ & $\mathbf{5}$ & $\mathbf{1 0}$ \\
\hline Ripe Fruit & $36,37 \mathrm{Aa}$ & $22,50 \mathrm{Ca}$ & $30,83 \mathrm{Ba}$ \\
Green Fruit & $37,20 \mathrm{Aa}$ & $23,13 \mathrm{Ba}$ & $26,18 \mathrm{Ba}$ \\
Leaf & $35,10 \mathrm{Aa}$ & $16,10 \mathrm{Bb}$ & $13,73 \mathrm{Bb}$ \\
Inflorescence & $40,43 \mathrm{Aa}$ & $23,30 \mathrm{Ba}$ & $26,83 \mathrm{Ba}$ \\
\hline
\end{tabular}

Source: Authors (2015)

In where: Averages followed by the same capital letter in the row, and lowercase letter in the column do not differ one another by Scott-Knot test at $5 \%$ of significance level.

Zahed et al. (2010), working with Schinus molle found that the essential oil of fruits collected at the fruiting period showed less interference on the seed germination and root elongation of Triticum aestivum L., in relation to the essential oil obtained from leaves. We found a similar result, in relation to the aqueous extract, where RE at $40 \mathrm{mg} \cdot \mathrm{mL}^{-1}$ was equal to zero for the extract obtained from leaf, and equal to $3.43 \mathrm{~mm}$ for that obtained from ripe fruit. 
Similar characteristics were found for both aqueous and ethanolic extracts, in relation to $\mathrm{G}$ of Lactuca sativa, when exposed to high concentration of the extract, with $9 \%$ of germination for ripe fruits and $33 \%$ for leaves, in case of aqueous extract. It stands out, however, that even in different solvents and methodological procedures of extraction, all results show the potential phytotoxicity of Schinus molle.

Borella, Martinazzo and Aumonde (2010) and Nogueira et al. (2017), investigating the allelopathic activity of leaf extract of Schinus molle, in seeds of Raphanus sativus L. CV. Crimsom Gigante and seeds of Lactuca sativa, respectively, found reduction of germination, germination velocity index, velocity of germination and root elongation. These results showed the species toxicity and they are a hint that the phytotoxic effect of Schinus molle is regardless of the methodology of compounds extraction, at least those tested so far, and of the structures used in the experiment. Besides, papers approaching about Schinus spp. also showed the toxic effect of this plant species against other plants (PAWLOWSKI; SOARES, 2007; SOUZA et al., 2007; PAWLOWSKI et al., 2012).

According to our results, we found that RE was more sensitive parameter, since at 5 and $10 \mathrm{mg} \cdot \mathrm{mL}^{-1}$, either from ethanolic or from aqueous extracts, we found a differentiated effect among the structures. These is probably due to the fact of roots stays in direct contact with allelochemical compounds in the substrate (CHON; COUTTS; NELSON, 2000). Chung, Ahn and Yun (2001) also suggest that due to this contact, the response may have higher intensity in the parameters related to that structure. Moreover, different types of extracts may promote differentiated effects in the roots growth (BELINELO et al., 2008).

There is a relation between MI and RE (ANDRADE; DAVIDE; GEDRAITE, 2010), since plant growth is directly related to cellular multiplication (HARASHIMA; SCHNITTGER, 2010). This relation is also shown here, once there was reduction of $\mathrm{MI}$ and RE in all treatments.

In the same way as Andrade, Davide and Gedraite (2010),Pereira et al. (2013b), 
Andrade-Vieira et al. (2014), Nogueira et al. (2017) and Govêa et al. (2020), working with Lactuca sativa, we also identified changes in the cell cycle as well as we quantified structural abnormalities in the chromosomal complement, which are both aneugenics as clastogenic. These abnormalities are directly related to toxicity of the plant specimen. Pawlowski et al. (2012), also found different structural abnormalities in the DNA of onion and lettuce, and affirm that these were caused by substances found in the essential oil of the Schinus molle.

Although the use of Schinus molle in projects of reforestation in degraded areas as well its use in urban afforestation has been recommended (BACKES; IRGANG, 2002), this practice must be carefully seen, since we showed the phytotoxicity of this species, fact that can influence the growth of other plants and organisms in the region, affecting the environment composition.

\section{CONCLUSIONS}

All assessed parameters showed phytotoxic effect of Schinus molle. The concentrations of ethanolic and aqueous extracts showed a correlation for the most of the tested plant structures, except the ethanolic extract of the ripe fruits, in relation to dry biomass, which did not have any interference. Comparing leaves, inflorescence, green fruits, and ripe fruits, the green fruits had the highest toxicity. Therefore, Schinus molle was phytotoxic in the experiment involving lettuce, regardless the solvent and methodology used in the extraction of compounds and plant structures.

\section{ACKNOWLEDGEMENTS}

The authors would like to thank CAPES (Coordenação de Aperfeiçoamento de Pessoal de Nível Superior) for the postdoctoral fellowship PRODOC to Dr. Nadia Alves Campos (AUX-PE-PRODOC 2646.2010) and fellowship PET to Professor Sandro Barbosa, CNPq (Conselho Nacional de Desenvolvimento Científico e Tecnológico) and FAPEMIG (Fundação de Amparo à Pesquisa do Estado de Minas Gerais) for funding and research grants awarded to conduct this study. 


\section{REFERENCES}

ALVES, S. M.; ARRUDA, M. S. P.; SOUZA FILHO, A. P. S. Biossíntese e distribuição de substâncias alelopáticas. In: SOUZA FILHO, A. P.; ALVES, S. M. Alelopatia: princípios básicos e aspectos gerais. Belém: EMBRAPA Amazônia Oriental, 2002. p. 79-102.

ANDRADE, L. F.; DAVIDE, L. C.; GEDRAITE, L. S. The effect of cyanide compounds, fluorides, aluminium, and inorganic oxides present in spent pot liner on germination and root tip cells of Lactuca sativa. Ecotoxicology and Environmental Safety, Albany, v. 73, n. 4, p. 626-631, maio 2010.

ANDRADE-VIEIRA, L. F. et al. Effects of Jatropha curcas oil in Lactuca sativa root tip bioassays. Anais da Academia Brasileira de Ciência, Rio de Janeiro, v. 86, n. 1, p. 373-382, mar. 2014.

BACKES, P.; IRGANG, B. Árvores cultivadas no Sul do Brasil: Guia de identificação e interesse paisagístico das principais espécies exóticas. Porto Alegre: Paisagem do Sul Porto, 2004. 325 p.

BRASIL. Farmacopéia Brasileira. Brasília: Agência Nacional de Vigilância Sanitária, 2010. v. 2. $560 \mathrm{p}$.

BELINELO, V.J. et al. Alelopatia de Arctium minus Bernh (Asteraceae) na germinação e crescimento radicular de sorgo e pepino. Revista Caatinga, Mossoró, v.21, n. 4, p. 12-16, out./dez. 2008.

BORELLA, J.; MARTINAZZO, E. G.; AUMONDE, T. Z. Atividade alelopática de extratos de folhas de Schinus molle L. sobre a germinação e o crescimento inicial do rabanete. Revista Brasileira de Biociências, Porto Alegre, v. 9, n. 3, p. 398-404, jul./set. 2011.

CHON, S. U.; COUTTS, J. H.; NELSON, C. J. Effects of light, growth media, and seedling orientation on bioassays of alfalfa autotoxicity. Agrononomy Journal, Madison v. 92, n. 4, p. 715-720, jul. 2000.

CHUNG, I. M.; AHN, J. K.; YUN, S. J. Assessment of allelopathic potential of barnyard grass (Echinochloa crus-galli) on rice (Oryza sativa L.) cultivars. Crop Protection, Toowoomba, v. 20, n. 10, p. 921-928, dez, 2001.

FENNER, R. et al. Plantas utilizadas na medicina popular brasileira com potencial atividade antifúngica. Revista Brasileira De Ciências Farmacêuticas, São Paulo, v. 42, p. 370-394, jul./ set. 2006.

FERREIRA, A. G.; AQUILA, M. E. A. Alelopatia: uma área emergente da ecofisiologia vegetal. Revista Brasileira de Fisiologia Vegetal, Campinas, v. 12, nesp, p. 175-204, jul. 2000.

GOBBO-NETO, L.; LOPES, N. P. Plantas Medicinais: fatores de influência no conteúdo de metabólitos secundários. Química Nova, São Paulo, v. 30, n. 2, p. 374-381, out. 2007.

GOVÊA, K. P. et al. Allelochemical Activity of Eugenol-Derived Coumarins on Lactuca sativa L. Plants, [s. I.], v. 9, n. 4, p. 533, abr. 2020.

HARASHIMA, H.; SCHNITTGER, A. The integration of cell division, growth and differentiation. Current Opinion in Plant Biology, Saint Louis, v. 13, n. 1, p. 66-74, fev. 2010. 
MARTINS, M. R. et al. Antioxidant, antimicrobial and toxicological properties of Schinus molle L. essential oils. Journal of Ethnopharmacology, Leiden, v. 151, n. 1, p. 485-492, jan. 2014.

NASCIMENTO, I. L. et al. Influência de partes vegetais do Tamarindus indica L. como efeito alelopático na germinação de alface. Agropecuária Científica no Semi-árido, Campina Grande, v. 8, n. 4, p. 97-101, out./dez. 2012.

NOGUEIRA, M. L. et al. Allelopathic Effects of Aqueous and Ethanolic Leaves Extracts of Schinus molle L. under Different Kinds of Pruning. Journal of Agricultural Science and Technology A, v. 7, p. 169-177, 2017.

PAWLOWSKI, A. et al. Essential oils of Schinus terebinthifolius and Schinus molle (Anacardiaceae): mitodrepessive and aneugenic inducers in onion and lettuce root meristems. South African Journal of Botany, Pietermaritzburg, v. 80, p. 96-103, maio 2012.

PAWLOWSKI, A.; SOARES, G. L. G. Inibição da germinação e do crescimento radicial de alface (Lactuca sativa cv. Grand Rapids) por extratos alcoólicos de espécies de Schinus L. Revista Brasileira de Biociência, Porto Alegre, v. 5, n. 2, p. 666-668, jul. 2007.

PEREIRA, M. P. et al. Fitotoxicidade do chumbo na germinação e crescimento inicial de alface em função da anatomia radicular e ciclo celular. Agro@mbiente On-line, Roraima, v. 7, n. 1, p. 36-43, jan./abr. 2013 a.

PEREIRA, M. P. et al. Lead tolerance during germination and early growth of the Brazilian peppertree and the morpho-physiological modifications. Revista Ciências Agrárias, Belém, v. 56, p. 72-79, dez. 2013b.

R DEVELOPMENT CORE TEAM. R: a language and environment for statistical computing. Viena: R Foundation for Statistical Computing, 2013.

REIGOSA, M. et al. Allelopathic research in Brazil. Acta Botanica Brasilica, Feira de Santana, v. 27. n. 4, p. 629-646, out./dez. 2013.

RIBEIRO, L. O. et al. Fitotoxicidade de extratos foliares de barbatimão [Stryphnodendron adstringens (Mart.) Coville] em bioensaio com alface. Revista Brasileira de Biociências, Porto Alegre, v. 10, n. 2, p. 220-225, abr./jun. 2012.

RICE, E. L. Allelopathy. New York: Academic Press, 1984.

SANTOS, A. C. A. et al. Caracterização química de populações de Schinus molle L. do Rio Grande do Sul. Revista Brasileira de Biociências, Porto Alegre, v. 5, supl., p. 1014-1016. jul. 2007.

SIMÕES, M. S. et al. Padronização de bioensaios para detecção de compostos alelopáticos e toxicantes ambientais utilizando alface. Biotemas, Florianópolis, v. 26, n. 3, p. 29-36, set. 2013.

SINIMBU, G.; COLEY, P. D.; LEMES, M. R. Do the antiherbivore traits os expanding leaves in the neo tropical tree Inga paraensis (Fabacea) vary eith light avaliability. Oecologia, Buenos Aires, v. 170, n. 3, p. 669-676, nov. 2012.

SOUZA, C. S. M. et al. Alelopatia do extrato aquoso de folhas de aroeira na germinação de sementes de alface. Revista Verde de Agroecologia e Desenvolvimento Sustentável, Mossoró, v. 2, n. 2, p. 96-100, jul./dez. 2007.

ZAHED, N. et al. Allelopathic effect of Schinus molle essential oils on wheat germination. Acta Physiologiae Plantarum, Gewerbestrasse, v. 32, n. 6, p. 1221-1227, nov. 2010. 


\section{Authorship Contribution}

\section{1 - Marina Lima Nogueira}

Biologist, Dr.

https://orcid.org/0000-0002-6110-2700•malima_nogueira@hotmail.com

Contribution: Conceptualization, Data curation, Formal Analysis, Investigation, Methodology, Project administration, Writing - original draft, Writing - review \& editing

\section{2 - Nádia Alves Campos}

Biologist, Dr.

https://orcid.org/0000-0001-6576-6531•nadialvesnep@hotmail.com

Contribution: Data curation, Writing - original draft, Writing - review \& editing

\section{3 - Simone Cristina dos Santos}

Biologist, MSc.

https://orcid.org/0000-0003-2420-5177•si.c.santos@hotmail.com

Contribution: Investigation, Validation, Writing - original draft, Writing - review \& editing

\section{4 - Luiz Alberto Beijo}

Mathematician, Dr., Professor

https://orcid.org/0000-0002-3286-5602 •prof.beijo@gmail.com

Contribution: Data curation, Writing - original draft, Writing - review \& editing

\section{5 - Sandro Barbosa}

Biologist, Dr., Professor

https://orcid.org/0000-0001-7321-0007•sandrobiogen@gmail.com

Contribution: Project administration, Data curation, Writing - original draft, Writing review \& editing

\section{How to quote this article}

Nogueira, M. L.; Campos, N. A.; Santos, S. C.; Beijo, L. A.; Barbosa, S. The species used in urban afforestation can present phytotoxicity - a case of study of Schinus molle L. Ciência Florestal, Santa Maria, v. 31, n. 1, p. 66-84, 2021. DOI 10.5902/1980509820597. Available from: https:// doi.org/10.5902/1980509820597. Accessed: xx abbreviated month 202x. 